\title{
Artikel
}

\section{Kan een non disclosure agreement worden ontbonden?}

Prof. mr. dr. T.H.M. van Wechem en mr. A.J. Rijsterborgh*

\section{Inleiding}

In een geheimhoudingsovereenkomst, ook wel confidentiality agreement of non disclosure agreement (hierna: NDA) genoemd, spreken partijen af bepaalde gegevens van elkaar geheim te zullen houden. ${ }^{1}$ Hoewel 'de NDA' geen vastomlijnd (juridisch) begrip is, wordt hiermee in de praktijk veelal gedoeld op een separate geheimhoudingsovereenkomst. Dit in tegenstelling tot 'het geheimhoudingsbeding' als onderdeel van een meeromvattende overeenkomst (bijvoorbeeld een vaststellingsovereenkomst). Als gevolg van de Wet bescherming bedrijfsgeheimen (Wbb) - waarop hierna zal worden ingegaan - is het belang van het contractueel waarborgen van bedrijfsgeheimen toegenomen. ${ }^{2}$

In dit artikel onderzoeken wij of het in een handelsrelatie met het oog op ontbinding (art. 6:265 Burgerlijk Wetboek (BW)) uitmaakt of geheimhouding in een NDA of in een meeromvattende overeenkomst is overeengekomen. Wij beperken ons hierbij tot een tweepartijenverhouding naar Nederlands recht. Hoewel ontbinding normaliter zal worden uitgesloten (en hierover zel-

Prof. mr. dr. T.H.M. van Wechem is hoogleraar Corporate Legal Counselling aan de Open Universiteit en zelfstandig juridisch adviseur te Amsterdam. Mr. A.J. Rijsterborgh is schrijfjurist in het gerechtshof Den Haag en werkt als buitenpromovendus aan de Open Universiteit aan een proefschrift over partiële aantasting van overeenkomsten. De auteurs schrijven dit artikel op persoonlijke titel.

1. Naast geheimhouding spreken partijen veelal af dat de verstrekte gegevens eveneens op beperkte wijze door de ontvangende partij mogen worden gebruikt.

2. Stb. 2018,369 . De Wet bescherming bedrijfsgeheimen is op 23 oktober 2018 in werking getreden den wordt geprocedeerd), kan het antwoord op deze vraag opstellers van contracten helpen bij hun afweging hoe zij bepaalde rechtsbetrekkingen over vertrouwelijke informatie vorm willen geven.

Wij zullen eerst kort ingaan op de juridisch te onderscheiden bedrijfsgeheimen die contractueel kunnen worden geborgd en de gebruikelijke remedies bij nietnakoming van een NDA (par. 2 en 3). Vervolgens zal worden onderzocht hoe een NDA (normaliter) juridisch moet worden gekwalificeerd (par. 4) en of deze kan worden ontbonden (par. 5). Hierbij wordt ook aandacht besteed aan de vraag wat de ontbinding van een NDA concreet zou betekenen. Aan de hand hiervan zal worden onderzocht of het uitmaakt of geheimhouding wordt afgesproken in een NDA, als beding in een meeromvattende overeenkomst of in een al dan niet samenhangende overeenkomst (par. 6). Wij sluiten af met een conclusie (par. 7).

\section{Vermogensrechtelijke kwalificatie van 'bedrijfsgeheimen' en de bescherming hiervan}

Bedrijfsgeheimen moeten juridisch worden onderscheiden van subjectieve rechten, zoals rechten van intellectueel eigendomsrecht (IE-recht). ${ }^{3}$ Laatstgenoemde rechten kwalificeren vermogensrechtelijk als een 'exclusief recht' en zijn goederenrechtelijk overdraagbaar. Daar staat tegenover dat het IE-recht subjectieve rechten

3. Zie hierover C.H. Sieburgh, Van geen inbreuk op een recht naar inbreuk op geen recht, Rechtsgeleerd Magazijn THEMIS 2019/1. 
slechts beperkt in tijd beschermt. Voor bedrijfsgeheimen (hierna: gewone bedrijfsgeheimen) geldt dit allemaal niet. ${ }^{4}$

Gewone bedrijfsgeheimen kunnen weer worden opgedeeld in geheimen die nog niet beschermd worden door een IE-recht, ${ }^{5}$ bijvoorbeeld een uitvinding die door de uitvinder nog moet worden gepatenteerd, en geheimen die niet door een IE-recht kunnen worden beschermd, zoals een prijslijst of een opsomming van potentiële klanten. Doordat naar Nederlands recht geen 'eigendom' van gewone bedrijfsgeheimen wordt erkend, bestaat door het beschikken hierover geen aanspraak op uitsluitende toepassing van de verworvenheid waar het recht op gericht is. ${ }^{6}$ Feitelijke bescherming wordt uiteraard geboden door de omstandigheid dat men slechts van iets kan profiteren wanneer hiermee bekendheid bestaat. $^{7}$ Een houder van een gewoon bedrijfsgeheim is daarmee echter niet beschermd tegen een gelijktijdige of latere 'ontdekking' hiervan. ${ }^{8}$ Iedere concurrent die bij toeval tot dezelfde prijslijst of opsomming van klanten komt, mag hier dus in beginsel gebruik van maken. ${ }^{9}$ De 'houder' van een gewoon bedrijfsgeheim heeft enkel mogelijkheden om op te treden indien de kennis van zijn bedrijfsgeheim op onregelmatige wijze is verworven. De 'houder' van een dergelijk bedrijfsgeheim kan, indien deze geheimhouding contractueel is overeengekomen, zijn wederpartij aanspreken op wanprestatie (art. 6:74 BW; zie ook par. 4). Buiten contract kan de houder kort gezegd - een derde slechts aanspreken op grond van onrechtmatige daad ${ }^{10}$ of ongerechtvaardigde verrijking.

Hij die over een gewoon bedrijfsgeheim beschikt, kan, mits aan bepaalde eisen is voldaan, wel 'extra' rechtsbescherming ontlenen aan de Wbb. Deze wet, die de

4. Kamerstukken II $2017 / 18,34821$, nr. 3 (MvT), p. 4. Het is natuurlijk wel mogelijk dat een bedrijfsgeheim, als gevolg van een later verworven patent, 'evalueert' tot een intellectueel eigendomsrecht.

5. Zie over schending geheimhoudingsbedingen en octrooieerbaarheid, P.G.F.A. Geerts, Bescherming van de intellectuele eigendom, Kluwer: Deventer 2017, p. 36.

6. J.L.R.A. Huydecoper, Knowhow en het vermogensrecht, MvV 2008/7/8, p. 158

7. Eventuele strafrechtelijke consequenties of gevolgen voor arbeidsrechtelijke verhoudingen laten we in dit artikel buiten bespreking.

8. Sterker nog, een houder die nalaat zijn gewone bedrijfsgeheim - dat hiervoor als zodanig wel geschikt is - te beschermen middels een IErecht (bijv. die ene pakkende handelsnaam van een nieuw op te richten vennootschap middels registratie hiervan), loopt het risico dat hij het recht verliest om de naam te voeren aan een partij die dit recht wel verwerft. Dit is ook het geval indien laatstgenoemde het gewone bedrijfsgeheim slechts heeft leren kennen in (regelmatig) afgebroken onderhandelingen met de houder. Zie HR 24 december 1999, ECLI:NL:PHR: 1999:ZC3064, NJ 2000/185

9. IE-rechten bieden (ook) niet altijd bescherming tegen een latere ontdekking van hetzelfde. Ook op basis van het auteursrecht en het niet-ingeschreven modelrecht kan niet worden opgetreden tegen een derde die 'bij toeval' - dus zonder kennis van het beschermde werk/model eenzelfde werk/model heeft gecreëerd.

10. Reeds in het arrest Lindenbaum/Cohen oordeelde de Hoge Raad dat het schenden van een bedrijfsgeheim onder omstandigheden in strijd kan zijn met de maatschappelijke betamelijkheid (art. 6:162 lid 2 BW); zie HR 31 januari 1919, ECLI:NL:HR:1919:AG1776, NJ 1919, p. 161. implementatie vormt van een Europese richtlijn, ${ }^{11}$ beoogt niet de vermogensrechtelijke status van gewone bedrijfsgeheimen te wijzigen, maar geeft aan de 'houder' ${ }^{\prime 2}$ hiervan meer mogelijkheden om tegen onrechtmatige inbreuk op te komen. ${ }^{13}$ Zo bevat de Wbb belangrijke processuele waarborgen, gericht op een betere bescherming van de (gestelde) bedrijfsgeheimen gedurende een gerechtelijke procedure. ${ }^{14}$ Daarnaast is beoogd de positie van een geheimhouder ook materieel te verbeteren. Zo bevat de wet in artikel 1 een (ruime) definitie van het begrip 'bedrijfsgeheim'. Dit wordt omschreven als informatie die aan de volgende drie, cumulatieve, voorwaarden voldoet: (1) de informatie moet geheim zijn, (2) de informatie heeft handelswaarde omdat zij geheim is, en (3) de houder heeft het bedrijfsgeheim onderworpen aan redelijke maatregelen om hem geheim te houden. ${ }^{15,16}$

Ten aanzien van de laatste voorwaarde, de redelijke maatregelen die genomen moeten worden om het bedrijfsgeheim te beschermen, wordt in de memorie van toelichting opgemerkt dat hierbij in handelscontracten moet worden gedacht aan een geheimhoudingsbeding. ${ }^{17}$ Wanneer bij de uitwisseling van gewone bedrijfsgeheimen in handelsrelaties tussen partijen niet schriftelijk vertrouwelijkheid is overeengekomen, zal immers niet van 'redelijke maatregelen' als bedoeld in de Wbb sprake zijn. ${ }^{18}$ Het slagen van een actie uit onrechtmatige daad of welke is gebaseerd op toepassing van de aanvullende werking van de redelijkheid en billijkheid, zal in

11. Richtlijn 2016/943/EU van het Europees Parlement en de Raad van 8 juni 2016 betreffende de bescherming van niet-openbaar gemaakte knowhow en bedrijfsinformatie (bedrijfsgeheimen) tegen het onrechtmatig verkrijgen, gebruiken en openbaar maken daarvan (PbEU 2016, L157). Deze richtlijn is zelf weer gebaseerd op het WTO-Verdrag de overeenkomst inzake de handelsaspecten van de intellectuele eigendom (Agreement on Trade-Related aspects of Intellectual Property Rights).

12. Dit ziet niet op de in Boek 3 BW bedoelde houder.

13. Zie hierover uitgebreid R. Mellenbergh \& E.A. Zonnenberg-Mellenbergh, Bedrijfsgeheimen in vermogensrechtelijk perspectief, WPNR 7213 , p. 811-819, die niet uitsluiten dat een bedrijfsgeheim ingevolge de $\mathrm{Wbb}$ een relatief recht is en mogelijk zelfs een relatief vermogensrecht.

14. 15 Zie hierover R.M. Hermans, Bedrijfsgeheimen en andere vertrouwelijke informatie in de civiele procedure, in: Y. Borrius (red.), Geschriften vanwege de Vereniging Corporate Litigation 2018-2019, Deventer: Kluwer, p. 319-350. Zie over maatstaf 'rechtsbetrekking' als bedoeld in art. 843a Rv ter zake exhibitievordering vanwege mogelijke inbreuk op IE-recht en 'normaal' bedrijfsgeheim respectievelijk HR 13 maart 2018, ECLI:NL:HR:2018:1775, NJ 2019/70, m.nt. Ch. Gielen en A.I.M. van Mierlo; HR 10 juli 2020, ECLI:NL:HR:2020:1251.

15. Kamerstukken II 2017/18, 34821, nr. 3 (MvT), p. 6.

16. Tegelijkertijd is echter de eis dat de onrechtmatige inbreuk 'toerekenbaar' moet zijn (art. 6:162 lid 3 BW), 'vervangen' door het (striktere) criterium van 'wist of moest weten'. Dit zal het naar verwachting lastiger maken om (direct) inbreuk makende partijen of zij die profiteren van wanprestatie in rechte aan te spreken. Zie hierover $C$. van Nispen, Een nieuw quasi-IE-Recht in wording: het bedrijfsgeheim, BIE januari/ februari 2018, p. 7 en 9.

17. Kamerstukken II 2017/18, 34821, nr. 3 (MvT), p. 17.

18. HR 19 januari 2018, ECLI:NL:HR:2018:56, NJ 2018/237, m.nt. J.H. Spoor, r.o. 3.2.2. Vgl. Rb. Oost-Brabant 10 oktober 2018, ECLI:NL:RBOBR:2018:5007, r.o. 4.9.4; M.S. Jorissen, Redelijke maatregelen ter bescherming van bedrijfsgeheimen, Weert: Celsus Juridische Uitgeverij 2019, p. 23 
een dergelijk geval vermoedelijk kleiner zijn. ${ }^{19}$ Bij inbreuk na afloop van de contractueel overeengekomen termijn voor geheimhouding ligt dat mogelijk genuanceerder. ${ }^{20}$ In ieder geval lijkt met de inwerkingtreding van deze wet dus (ook) het belang van contractuele geheimhouding te zijn toegenomen.

\section{3 'Gebruikelijke' remedies bij schending van de NDA}

Als gevolg van het feit dat de NDA (veelal) naar haar aard een obligatoire overeenkomst is (zie par. 4), kan hiervan in theorie in rechte nakoming worden gevorderd op last van een dwangsom. ${ }^{21}$ Hoewel geheimen zich naar hun aard vaak slechts éénmaal laten openbaren, kan een wederpartij, nadat zij (alleen) jegens partij X haar mond voorbij heeft gepraat, worden veroordeeld in de toekomst dit geheim niet (ook) aan anderen te openbaren. ${ }^{22}$ In de praktijk wordt de schending van een NDA echter veelal (primair) gesanctioneerd met een contractuele boete (art. 6:91 e.v. BW). Een dergelijk boetebeding houdt meestal in dat de betreffende partij ${ }^{23}$ voor iedere schending onder de NDA en/of iedere dag dat deze schending voortduurt, een boete van een $\mathrm{X}$ bedrag verbeurt. $^{24}$ Redengevend om te kiezen voor een boetebeding is dat het voor de partij wier geheimen worden geschonden, aangenomen dat dit in rechte kan worden aangetoond, veelal moeilijk zal zijn om te onderbouwen dat hierdoor schade is geleden en wat de omvang van deze schade dan is. ${ }^{25}$ Hiervoor zal immers de lastige vergelijking moeten worden gemaakt tussen de positie van

19. E. van der Vliet \& P.J. van der Korst, Bescherming van bedrijfsgeheimen in het arbeidsrecht, TAC 2020, april, p. 28.

20. Hoewel een onbepaalde tijd voor geheimhouding op het eerste gezicht redelijk lijkt, dient bedacht te worden dat de overeengekomen termijn uiteindelijk een onderhandelingsresultaat is, waarbij de termijn voor geheimhouding veelal - gemakshalve - is verbonden aan de eventuele overige verplichtingen uit een overeenkomst (zoals een non-concurrentiebeding, een relatiebeding enz.).

21. Vgl. A.C. van Schaick, Bewijsovereenkomsten en geheimhoudingsafspraken, NTBR 2006, p. 18.

22. A.C. van Schaick, Blijvende onmogelijkheid, NTBR 2012, p. 40.

23. Indien de 'partij' een vennootschap is, wordt veelal voorzien in een clausule, waardoor zij ook 'kwalitatief' aansprakelijk is voor schendingen van haar (voormalige) medewerkers van onder de NDA verkregen bedrijfsgeheimen. Als gevolg van bewijsproblemen blijft ook een dergelijke bepaling veelal een papieren tijger, waarbij bedacht dient te worden dat geheime knowhow zich kan opslaan in het menselijk brein. Toch raden wij $u$ aan om bij een NDA of geheimhoudingsclausule eens de vraag te stellen wat rechtens is als een medewerker van de wederpartij onder de NDA in dienst treedt bij de grootste concurrent van de partij die de informatie heeft verstrekt. Wanneer u indachtig deze vraag bij het lezen van de geheimhoudingsclausule of de NDA nerveus wordt, wordt het wellicht tijd deze aan te passen.

24. Hierbij dient wel bedacht te worden dat een dergelijke bepaling minder nuttig is op het moment dat de wederpartij een geheim publiekelijk maakt (bijv. door een publicatie op het internet). Bij een dergelijke schending is het geheim immers in één keer voor altijd verklapt en kan de wederpartij de verbintenis in het geheel niet meer nakomen.

25. H.J. de Kluiver, Overnamecontracten, letters of intent en garanties, O\&F 200358, p. 37 de openbaar makende partij $n u$ met de situatie dat de wederpartij partij haar plicht zou zijn nagekomen. ${ }^{26}$

Het valt daarentegen niet altijd uit te sluiten dat de openbaarmaking van bepaalde geheime informatie dermate schadelijk is dat de opgenomen boetebepaling onvoldoende redres biedt. Hierbij kan bijvoorbeeld worden gedacht aan een partij die in een controlled auction de biedingsregels overtreedt (bid rigging), waardoor de doelwitvennootschap uiteindelijk voor een lagere prijs wordt verkocht. ${ }^{27}$ In de NDA wordt daarom meestal wel het recht voorbehouden om in plaats van de boete aanspraak te maken op vergoeding van de (hogere) hierdoor werkelijk geleden schade.

\section{Juridische kwalificatie van de NDA}

Alvorens de vraag te beantwoorden of een NDA kan worden ontbonden, zullen wij deze eerst juridisch duiden. Hierbij past de kanttekening dat over de NDA weinig algemeens te zeggen valt, omdat de juridische kwalificatie altijd wordt bepaald door de specifieke partijafspraken. Toch veroorloven wij ons enige algemene opmerkingen.

Veelal wordt in de praktijk een onderscheid gemaakt tussen de 'eenzijdige' en de 'wederkerige' NDA. In dit verband wordt van 'wederkerigheid' gesproken wanneer beide partijen over en weer afspreken elkaars geheime informatie vertrouwelijk te houden. ${ }^{28}$ Hierbij kan bijvoorbeeld gedacht worden aan partijen die een samenwerking willen aangaan in het kader van een door hen op te richten joint venture. De 'eenzijdige' NDA is het document op grond waarvan een van de contractspartijen bepaalde geheimen deelt (hierna: de openbarende partij) en de wederpartij (hierna: de ontvangende partij) zich verplicht deze informatie vertrouwelijk te zullen behandelen. De partij die als potentiële koper participeert in een controlled auction tekent veelal een dergelijke 'eenzijdige' NDA teneinde (de eerste) informatie over de doelwitvennootschap te verkrijgen.

Of een NDA een obligatoire overeenkomst is als bedoeld in artikel 6:213 lid $1 \mathrm{BW}^{29}$ hangt af van de vraag of sprake is van een 'meerzijdige rechtshandeling', 30

26. De 'vertaling' van het onregelmatig verkrijgen van een geheime klantenlijst door een concurrent naar een omzetdaling en een daarop gebaseerde schadevergoedingsvordering van de gelaedeerde zal in de praktijk niet altijd makkelijk te maken zijn.

27. D.A.M.H.W. Strik, Bid-rigging: to play or not to play - Over spelregels ter bewaking van de effectiviteit van controlled auctions, Ondernemingsrecht 2004, p. 204.

28. Zie o.m. J.G.A Struycken, NDA's, process letters, engagement letters, release letters en biedbrieven, Contracteren 2013/2, p. 72; M.J. Jansen \& D.R. de Breij, Documentatie in de 'voorfase' van een transactie, TOP 2013, september, p. 213.

29. Art. 6:213 BW luidt: 'Een overeenkomst in de zin van deze titel is een meerzijdige rechtshandeling, waarbij een of meer partijen jegens een of meer andere een verbintenis aangaan.'

30. Asser/Sieburgh 6-III 2018/2: 'Bij de meerzijdige rechtshandelingen is voor het intreden van rechtsgevolg de samenwerking van twee of meer personen nodig.' Vgl. hierover Tjong Tjin Tai, Meerpartijen- 
waaruit 'verbintenissen' voortvloeien. ${ }^{31}$ De term verbintenis wordt in het BW niet gedefinieerd (dit is door de wetgever expliciet aan de rechtswetenschap overgelaten), ${ }^{32}$ maar wordt in de Toelichting Meijers omschreven als slechts die rechtsbetrekking met een zuiver vermogensrechtelijk karakter. Het zuiver vermogensrechtelijke karakter betekent in dezen dat de schuldeiser van zo'n rechtsbetrekking een vorderingsrecht heeft dat in beginsel vatbaar is voor overdracht en executie (bijvoorbeeld de verbintenis tot betaling van een geldsom). ${ }^{33} \mathrm{De}$ Hoge Raad lijkt echter in zijn rechtspraak het 'vereiste' van een subjectief vermogensrecht voor zijn begrip van een verbintenis niet altijd doorslaggevend te achten, waardoor bijvoorbeeld ook contractuele zorgplichten door hem hieronder worden geschaard. ${ }^{34}$

Ontstaan onder een NDA verbintenissen voor partijen? Een verplichting van de openbarende partij om informatie te delen wordt hierin vrijwel nooit opgenomen. Vaak wordt in de NDA niet eens gespecificeerd welke informatie zal worden verstrekt. ${ }^{35}$ In de praktijk wordt veelal opgeschreven dat de openbarende partij, in het kader van een bepaalde relatie (bijvoorbeeld onderhandelingen of een samenwerking), mogelijk geheime informatie zal delen, maar een verplichting is dit niet. ${ }^{36}$ Een dergelijke 'verplichting' is daarom onzes inziens veelal onvoldoende bepaalbaar om als verbintenis te kunnen gelden (art. 6:227 BW). Ook als de belofte tot het verstrekken van geheime informatie wel doelgericht is, kan (achteraf) niet met zekerheid door de ontvangende partij worden vastgesteld of alle beloofde informatie is gedeeld. ${ }^{37}$ De ontvangende partij verplicht zich onder de NDA tot de prestatie om iets 'niet' te doen, namelijk - kort gezegd - de informatie aan derden door te geven (zoals in par. 2 is uiteengezet, zou de ontvangende partij zonder een dergelijke afspraak gewone bedrijfsgeheimen immers in beginsel mogen gebruiken en/of delen zonder jegens de openbarende partij een norm te schen-

overeenkomst en samenhangende overeenkomsten, Mon. BW nr. A 29, 2019, nrs. 7,8 en 9.

31. Parl. Gesch. Boek 6, p. 837; Asser/Sieburgh 6-III 2018/31.

32. Parl. Gesch. Boek 6, p. 37

33. Parl. Gesch. Boek 6, p. 38

34. HR 8 februari 2013, ECLI:NL:HR:2013:BY4600, NJ 2014/497, m.nt. J. Hijma; A.J. Rijsterborgh \& Z.D. Veldhoen, De onwenselijkheid van de toepassing van de klachtplicht uit art. 6:89 BW op vorderingen ex art. 2:9 BW: een dogmatisch en praktisch perspectief, MvV 2015/4, p. 103 (met verwijzingen); J.J. Valk, Het toepassingsbereik van de klachtplicht, MvV 2020/2, p. 43

35. J. Goettsch, De geheimhoudingsovereenkomst: aandachtspunten voor de fusie- en overnamepraktijk, V\&O 2015/4, p. 51.

36. Sterker nog, in sommige NDA's wordt een dergelijke verplichting zelfs expliciet uitgesloten

37. De Hoge Raad heeft o.a. op 29 april 2016 (ECLI:NL:HR:2016:765) en, voor bepaalbaarheid voor pandrechten op auteursrechten, 3 april 2020 (ECLI:NL:HR:2020:590 (ING/Schepel q.q.)) overwogen dat aan de bepaalbaarheid van art. 6:227 BW is voldaan wanneer de vaststelling van de verbintenissen naar van tevoren vaststaande criteria kan geschieden en dat die criteria een subjectief element kunnen inhouden. In het kader van een NDA kan dit schuren, omdat de vraag of en welke informatie verstrekt zal worden louter van de wil van een der partijen kan afhangen. Echter, om daaraan de conclusie te verbinden dat daarom geen verbintenissen uit een NDA kunnen voortvloeien, lijkt ons te ver gaan. den). ${ }^{38}$ De rechtsbetrekking is onzes inziens moeilijk zuiver vermogensrechtelijk te noemen, maar verdedigbaar is wel dat op de ontvangende partij toch een bepaalde zorgplicht ten opzichte van de openbarende partij komt te rusten. Als gezegd kan een dergelijke zorgplicht in lijn met de rechtspraak van de Hoge Raad (vermoedelijk) worden gelijkgesteld met een verbintenis. Dit zou deze rechtsbetrekking concreet en tweezijdig maken, ${ }^{39}$ waardoor gesproken kan worden van een verbintenis en kan een NDA onder de obligatoire overeenkomsten zoals bedoeld in artikel 6:213 lid $1 \mathrm{BW}$ worden geschaard. ${ }^{40}$

In het verlengde hiervan ligt de vraag of een NDA ook als een mederkerige overeenkomst ex artikel 6:261 lid 1 BW kan worden aangemerkt. Hoewel de - in de praktijk gehanteerde - term 'wederkerige NDA' (zie hiervoor) hierop lijkt te duiden, is dit - wat ons betreft - geen gegeven. Een overeenkomst is ingevolge artikel 6:261 lid $1 \mathrm{BW}$ pas wederkerig indien beide partijen een verbintenis op zich nemen ter verkrijging van de prestatie waartoe de wederpartij zich daartegenover jegens haar verbindt. Het 'ruilkarakter' is een wezenlijk kenmerk van de wederkerige overeenkomst. ${ }^{41} \mathrm{Op}$ de keper beschouwd wordt in een NDA slechts afgesproken dat één of meer ontvangende partijen bepaalde geheime informatie, waarover zij (eventueel) de beschikking verkrijgen, geheim zullen houden. Tegenover deze verplichting staat geen (afdwingbare) verplichting van de openbaar makende partij, waardoor van een wederkerige overeenkomst ex artikel 6:261 lid $1 \mathrm{BW}$ in onze optiek geen sprake is (wat men in de praktijk een 'wederkerige NDA' noemt, is juridisch gezien volgens ons niets meer dan tweemaal een eenzijdige obligatoire overeenkomst).

\section{Kan een NDA worden ontbonden krachtens de regels van artikel 6:265 BW?}

Op grond van artikel 6:265 BW geldt als uitgangspunt dat de wederpartij van de tekortschietende (in verzuim

38. Zie meer in het algemeen over verbintenissen om niet te doen en de 'inpasbaarheid' hiervan in het wettelijke systeem Van Schaick 2012, p. 40.

39. 'Concreet', omdat het gaat om een rechtsbetrekking tussen de contractpartijen. 'Tweezijdig', omdat tegenover de verplichting van de ontvangende tot de prestatie een corresponderend recht op nakoming van de openbaar makende partij bestaat. Vgl. Valk 2020, p. 46

40. Hierbij kan wel de vraag worden gesteld of een overeenkomst waaruit de verbintenis voortvloeit om iets niet te doen wel 'obligatoir' van aard is. Het kan worden bepleit dat een NDA hierdoor veeleer liberatoir van aard is en derhalve (toch) niet onder het bereik van art. 6:213 BW valt (Parl. Gesch. Boek 6, p. 837). Dit betekent dat dan de schakelbepaling van art. 6:216 BW bepalend is voor de vraag of de afdelingen $2 \mathrm{t} / \mathrm{m} 5$ van titel 5 van Boek 6 hierop van overeenkomstige toepassing zijn (hierdoor zou een NDA mogelijk ook niet op grond van dwaling kunnen worden vernietigd). $\mathrm{Vgl}$. in het kader van een samenlevingscontracten HR 21 februari 2014, ECLI:NL:HR:2014:416.

41. Parl. Gesch. Boek 6, p. 989. 
verkerende) schuldenaar het recht heeft een overeenkomst geheel of gedeeltelijk te ontbinden. ${ }^{42}$ Uit de tekst van artikel 6:265 lid $1 \mathrm{BW}$ blijkt dat hierin de ontbinding van 'de overeenkomst' geregeld wordt. Volgens Bakels is hierbij in eerste instantie gedacht aan de wederkerige overeenkomst als bedoeld in artikel 6:261 lid $1 \mathrm{BW} .{ }^{43}$ Dit lijkt ook logisch, nu artikel 6:265 $\mathrm{BW}$ is opgenomen in afdeling 6.5 .5 (wederkerige overeenkomsten).

$\mathrm{Nu}$ wij hiervoor hebben geconstateerd dat een NDA (normaliter) geen wederkerige overeenkomst betreft, zijn de bepalingen met betrekking tot ontbinding alleen dan hierop van toepassing indien schakelbepaling artikel 6:261 lid 2 BW hieraan niet in de weg staat. ${ }^{44}$ Deze schakelbepaling bepaalt, kort gezegd, dat het ontbindingsregime van overeenkomstige toepassing is op een rechtsbetrekking die strekt tot het wederzijds verrichten van prestaties, voor zover de aard hiervan zich hiertegen niet verzet. ${ }^{45}$

Zoals in paragraaf 4 uiteen is gezet, betreft het 'ruilkarakter' een wezenlijk kenmerk van de wederkerige overeenkomst. ${ }^{46}$ Volgens Bakels vereist dit ruilkarakter dat een partij wier wederpartij tekortschiet, zich door ontbinding kan bevrijden van de verplichting de tegenprestatie te verrichten waartoe zij zich heeft verbonden ter verkrijging van (het recht op) de prestatie. ${ }^{47}$ Hiervoor hebben wij uiteengezet dat het 'ruilkarakter'48 van de verplichtingen van partijen onder een NDA beperkt is. De aard van de $\mathrm{NDA}^{49}$ lijkt zich daarom tegen overeen-

42. De vraag wanneer een tekortkoming van voldoende gewicht is om een overeenkomst te ontbinden, laten wij in deze bijdrage buiten beschouwing. Zie hierover HR 28 september 2018, ECLI:NL:HR:2018:1810, NJ 2019/446, m.nt. J. Hijma

43. F.B. Bakels, Ontbinding van overeenkomsten (Monografieën BW), Kluwer: Deventer 2011, nr. 22.

44. Alvorens dit verder te onderzoeken verdient opmerking dat partijen dit in de eerste plaats natuurlijk zelf in de hand hebben, omdat de ontbindingsregeling van art. 6:265 e.v. BW van regelend recht is en daarom contractueel kan worden uitgesloten.

45. Op grond van deze schakelbepaling vallen bijv. ook zgn. 'onvolmaakte' wederkerige overeenkomsten onder het bereik van de ontbindingsbepalingen; Parl. Gesch. Boek 6, p. 989. Hierbij kan bijv. gedacht worden aan een overeenkomst van opdracht waarbij de opdrachtnemer een inspanningsverplichting op zich heeft genomen om ten behoeve van de verkoper een koopovereenkomst tot stand te brengen, waarbij de opdrachtnemer zich onvoldoende inspant en de opdrachtgever (die tot dan toe nog niets heeft gepresteerd, waardoor de overeenkomst tot dan toe in feite eenzijdig was) de overeenkomst wenst te beëindigen. VgI. HR 14 april 2000, ECLI:NL:PHR:2000:AA5516, NJ 2000/438.

46. Parl. Gesch. Boek 6, p. 989.

47. Bakels 2011, nr. 22

48. De Hoge Raad heeft in 2018 in een arrest over ontbinding van een borgtocht het belang van het ruilkarakter benadrukt (art. 6:261 lid 1 BW). Nu in het geval van borgtocht niet de schuldeiser, maar alleen de borg een verbintenis op zich neemt (art. 7:850 BW), kan laatstgenoemde deze overeenkomst niet ontbinden omdat hij meent dat de schuldeiser jegens hem tekort is geschoten. HR 15 juni 2018, ECLI:NL:HR: 2018:915, NJ 2019/278, m.nt. Jac. Hijma, r.o. 3.4.1. Mogelijk is wel, aldus de Hoge Raad, dat in verband met de borgtocht (ook) door de schuldeiser verplichtingen zijn aangegaan die in zodanig nauwe samenhang staan tot de verbintenis van de borg, dat sprake is van een rechtsbetrekking die strekt tot het wederzijds verrichten van prestaties in de zin van art. 6:261 lid 2 BW.

49. Het gegeven dat de wederpartij (ontvanger) zich veelal verbindt tot een belofte om 'niet te doen' (niet te openbaren), laat zich onzes inziens komstige toepassing van het ontbindingsregime te verzetten.

Meer praktische argumenten tegen toepasselijkheid van het ontbindingsregime op een NDA (of ten aanzien van de gevolgen van de ontbinding van een overeenkomst met een daarin opgenomen geheimhoudingsbeding) zijn de volgende. Het zou dan te betogen zijn, in het geval wat men een 'wederzijdse NDA' placht te noemen (zie hiervoor), dat ontbinding concreet betekent dat de wederpartij van de tekortschietende partij ook niet langer tot geheimhouding gehouden is. Dit effect zou dan weer genuanceerd worden doordat, blijkens de parlementaire geschiedenis, soms uit de overeenkomst volgt dat bepaalde verbintenissen, in weerwil van de (algehele) ontbinding, toch in stand blijven. ${ }^{50}$ Een soort postcontractuele goede trouw of een bepaalde mate van survival. Het schenden van een - onder de (ontbonden) NDA verkregen - bedrijfsheim blijft dan onrechtmatig. Ingevolge artikel 6:271 $\mathrm{BW}$ bevrijdt een ontbinding de partijen van de 'daardoor getroffen verbintenissen'. Ook zou betoogd kunnen worden dat de belofte om niet te openbaren niet wordt aangetast door de ontbinding en derhalve intact blijft en dat deze verbintenissen - door het bepaalde in artikel 6:271 BW - niet door de ontbinding getroffen worden. ${ }^{51}$

Indien de NDA wordt ontbonden op het moment dat al geheimen zijn uitgewisseld, kan de vraag worden gesteld naar de ongedaanmakingsverbintenissen (art. 6:271 $\mathrm{BW})$. De ontvangen informatie zal dan immers moeten worden 'teruggegeven'. Dit is lastig door het veelvuldig gebruik van back-ups. Hierdoor is het ondoenlijk en oncontroleerbaar of alle informatie daadwerkelijk is teruggegeven, maar hier dient te worden gerealiseerd dat de informatie zich ook vaak opslaat in de hoofden van mensen die bij de uitvoering van een en ander zijn betrokken. ${ }^{52}$ Dit probleem - dat overigens ook speelt bij de vernietiging van de NDA - kan het best praktisch worden opgelost door voor zover mogelijk specifieke bepalingen hierover op te nemen (bijvoorbeeld de verplichting om de back-ups te vernietigen). ${ }^{53}$

Dat een NDA niet kan worden ontbonden, lijkt op het eerste gezicht van weinig belang, omdat - zoals wij hiervoor bespraken - normaliter bij een tekortkoming andere remedies dan ontbinding kunnen worden ingezet

niet 'matchen' met de 'prestaties' waar art. 6:261 lid 2 BW betrekking op heeft.

50. Parl. Gesch. Boek 6, p. 1026. Hierbij wordt o.m. het voorbeeld gegeven van de huurder die, ook nadat de huurovereenkomst is ontbonden, nog zorg dient te dragen voor het gehuurde, totdat de huurder het object ter beschikking van de verhuurder heeft gesteld. Ook een ontbonden NDA zou op deze wijze voor partijen, die op grond hiervan vertrouwelijke informatie hebben ontvangen, nog 'nawerking' kunnen hebben; Tjong Tjin Tai 2019, nr. 12.

51. T.H.M. van Wechem \& J.H.M. Spanjaard, Overleeft de survival clause?', Contracteren 2017/3.

52. Om te verzoeken om die laatste informatie te 'erasen' gaat onzes inziens wel erg ver.

53. Jansen \& De Breij 2013, p. 215. 
(par. 3). ${ }^{54}$ Als ontbinding toch mogelijk zou zijn (en niet is weggecontracteerd), lijken de rechtsgevolgen hiervan beperkt; de verplichting om bedrijfsgeheimen geheim te houden blijft vermoedelijk bestaan. Hierna zullen wij betogen dat onze constatering dat een NDA niet kan worden ontbonden, wel interessant kan zijn wanneer partijen ook een meeromvattende overeenkomst, waarin al dan niet een geheimhoudingsbeding is opgenomen, zijn overeengekomen.

\section{Maakt het voor de mogelijkheid van ontbinding uit hoe de geheimhouding contractueel is} vormgegeven?

Partijen prefereren veelal gedetailleerde afspraken over de uitwisseling van bedrijfsgeheimen in een (aparte) NDA te regelen. Hierdoor wordt de 'hoofdovereenkomst', waar het partijen eigenlijk om te doen is (bijvoorbeeld een samenwerkingsovereenkomst), niet te veel 'bevuild' met ellenlange afspraken over de uitwisseling van bedrijfsgeheimen. ${ }^{55}$ Indien uitwisseling van geheime informatie een minder grote rol speelt in de rechtsverhouding, zullen partijen vermoedelijk eerder kiezen om hun geheimhoudingsafspraken te gieten in een beding in een meeromvattende (hoofd)overeenkomst.

Hiervoor is betoogd dat het twijfelachtig is of een NDA kan worden ontbonden. Het is dan interessant of het tekortschieten in een geheimhoudingsbeding - als onderdeel van een meeromvattende overeenkomst - dan wel kan leiden tot ontbinding van deze laatste overeenkomst. Hoewel deze vraag niet letterlijk aan de orde is gesteld, kan uit het Hoge Raad-arrest Tycho/Fisser worden afgeleid dat het schenden van een geheimhoudingsbeding onder omstandigheden een tekortkoming kan zijn die ontbinding van de (gehele) meeromvattende overeenkomst rechtvaardigt. ${ }^{56}$

In het arrest Tycho/Fisser was sprake van een beëindigingsovereenkomst tussen bedrijf A en ex-manager en aandeelhouder B. Hierin was ook een geheimhoudingsbeding opgenomen ten aanzien van het gebruik door $\mathrm{B}$ van A's gewone bedrijfsgeheimen. $B$ is vervolgens in dienst getreden bij een directe concurrent van A en heeft zich - in strijd met het geheimhoudingsbeding tijdens zijn werkzaamheden bediend van een 'geheime'

54. Het zal daarnaast sporadisch voorkomen dat een verkrijgende partij tekortschiet in haar verplichting tot geheimhouding, maar deze tekortkoming niet toerekenbaar is (hetgeen een vordering tot schadevergoeding op grond van art. 6:74 BW de pas afsnijdt, maar een ontbindingsvordering ex art. 6:265 BW niet in de weg staat).

55. Indien partijen met elkaar in onderhandeling treden, is er natuurlijk nog helemaal geen 'hoofdovereenkomst', waardoor de NDA op dat moment vaak nodig is om überhaupt tot zaken te kunnen komen.

56. HR 22 juni 2007, ECLI:NL:HR:2007:BA4122, NJ 2007/343. klantenlijst van A. A spreekt B in rechte aan en vordert onder andere ontbinding van de beëindigingsovereenkomst vanwege het tekortschieten door B van zijn verplichting tot geheimhouding. Het hof wijst deze vordering af, omdat het oordeelt dat de tekortkoming de ontbinding niet rechtvaardigt (en bovendien niet gebleken is dat als gevolg hiervan schade is ontstaan). De Hoge Raad casseert (en verwijst), omdat B slechts had bestreden dat hij tekort was geschoten, maar niet (subsidiair) had aangevoerd dat deze tekortkoming de ontbinding niet rechtvaardigt. ${ }^{57}$

De wederkerigheid van een overeenkomst is van belang voor de vraag of de overeenkomst kan worden ontbonden. Wanneer 'iedere tekortkoming', mits van voldoende gewicht, kan leiden tot de (algehele) ontbinding van de overeenkomst, wordt in feite geabstraheerd van deze wederkerigheid. ${ }^{58}$ Dit is op zichzelf genomen begrijpelijk, omdat een meeromvattende overeenkomst vaak een fijnmazige rechtsverhouding betreft (een 'totaalpakket' aan verbintenissen) en daarin moeilijk bepaalbaar is welke prestatie nu precies het spiegelbeeld vormt van welke verbintenis. De vraag kan daarom worden gesteld of dit geconstateerde verschil in de mogelijkheid tot ontbinding bezwaarlijk is. De discrepantie wordt interessanter wanneer twee partijen naast een (separate) NDA één of meerdere hiermee 'samenhangende overeenkomsten' zijn aangegaan.

In het geval van de Tycho/Fisser-casus (zie hiervoor) was het ook mogelijk geweest dat A en B eerst een NDA overeen waren gekomen alvorens de beëindigingsovereenkomst was uitonderhandeld. B kon dan in de tussenliggende periode elders gaan werken, terwijl A ervan 'verzekerd' was dat haar gewone bedrijfsgeheimen in de tussenliggende periode veilig waren. ${ }^{59}$

57. HR 22 juni 2007, ECLI:NL:HR:2007:BA4122, NJ 2007/343, r.o. 5.2.

58. Vgl. in dit verband ook HR 22 oktober 1999, ECLI:NL:HR: 1999:ZC2993, NJ 2000/208, m.nt. J. Hijma (Twickler). In die zaak was in een huurovereenkomst overeengekomen dat de exploitatie van het gehuurde zou geschieden op een wijze die niet in strijd was met enige wet. Tegenover deze verplichting van de huurder stond volgens ons geen, althans geen directe, verplichting van de verhuurder. Op enig moment is de huurder veroordeeld voor (o.a.) het overtreden van de Warenwet. Verhuurder vordert hierop ontbinding van de huurovereenkomst wegens (o.a.) het handelen in strijd met voornoemde bepaling. De kantonrechter ontbindt hierop de overeenkomst en veroordeelt de huurder het gehuurde te ontruimen. In hoger beroep vernietigt de rechtbank het bestreden vonnis. Volgens de rechtbank betreft de wijze waarop de exploitatie heeft plaatsgevonden niet de kern van de overeengekomen prestatie (de betaling van huurpenningen en het gebruiken van de grond voor de exploitatie van een marktkraam, zonder dat hierbij schade aan het perceel werd toegebracht). Dit betekent dat volgens de rechtbank niet zonder meer sprake is van een ontbinding rechtvaardigende tekortkoming, maar hiervoor een nadere belangenafweging vereist is. Vervolgens beslist de rechtbank dat ontbinding van de huurovereenkomst niet aan de orde is, omdat niet gebleken is dat Twickler een rechtens relevant belang had bij naleving van deze contractuele bepaling. De Hoge Raad casseert (en verwijst). Hij overweegt dat art. 6:265 lid 1 BW geen grond biedt voor een onderscheid in tekortkomingen van (1) bedingen die de kern van de prestatie betreffen, en (2) bedingen die niet de kern raken van de overeengekomen prestaties, waarbij de schuldeiser de stelplicht en de bewijslast draagt met betrekking tot in welke categorie de tekortkoming behoort.

59. Daarnaast wordt in de praktijk veel gebruikgemaakt van side letters. 


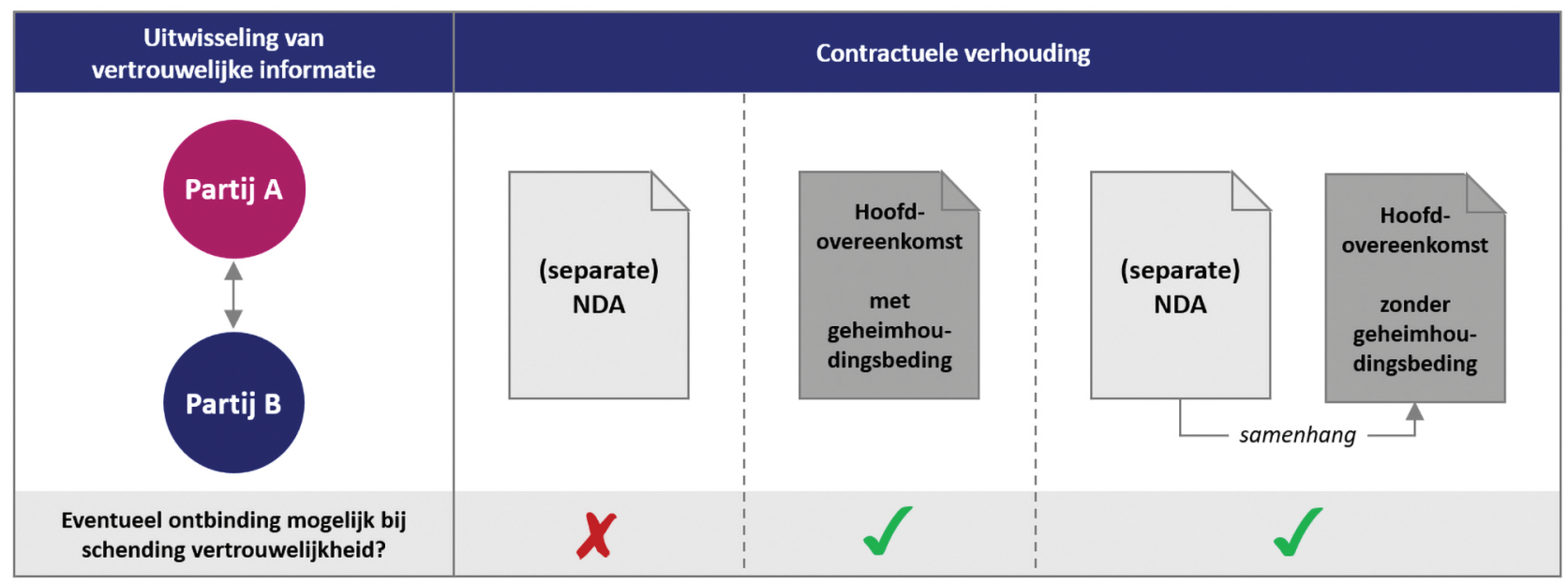

Kan A in het door ons gegeven voorbeeld de beëindigingsovereenkomst ook ontbinden wanneer B tekortschiet in zijn verplichtingen onder de NDA? Hiervoor is in de eerste plaats bepalend of de NDA en de beëindigingsovereenkomst in het gegeven voorbeeld 'samenhangende' overeenkomsten zijn (waaronder mede een voortbouwende overeenkomst als bedoeld in art. 6:229 BW kan worden verstaan). Dit kan het geval zijn indien partijen deze samenhang hebben 'ingecontracteerd'. Daarnaast kan de 'samenhang' tussen formeel gescheiden overeenkomsten (onder meer) worden aangenomen op grond van de (objectieve) partijbedoeling. Dit kan het geval zijn wanneer sprake is van een contractuele wederkerigheid die de afzonderlijke overeenkomsten overstijgt. ${ }^{60}$ In het door ons hiervoor aangedragen voorbeeld is het bijvoorbeeld bepleitbaar dat A op grond van de beëindigingsovereenkomst (hoofdovereenkomst) geen uitkering had gekregen op het moment dat hij niet (eerst) in de NDA had beloofd de bedrijfsgeheimen van $B$ te zullen respecteren. Dit betekent dat zelfs een tekortkoming van $\mathrm{A}$ (mits van voldoende gewicht) onder de NDA - die, zoals wij hebben betoogd, niet kan leiden tot een ontbinding van de NDA zelf - gevolgen kan hebben voor het recht van $\mathrm{B}$ om de beëindigingsovereenkomst te ontbinden. Hierbij merken wij wel op dat uit de rechtspraak van de Hoge Raad kan worden afgeleid dat ('niet-ingecontracteerde') 'samenhang' niet heel snel wordt aangenomen. ${ }^{61}$ Het separaat regelen van geheimhouding in een NDA, en door deze niet (expliciet) te linken aan de hoofdovereenkomst, kan derhalve de onzekerheid met zich brengen dat bij schending van een bepaling uit de NDA de benadeelde partij niet het recht geeft om de hoofdovereenkomst daarom te ontbinden.

Het vorenstaande wordt temeer interessant wanneer in de NDA ontbinding is uitgesloten en in de (samenhangende) hoofdovereenkomst ontbinding niet is uitgesloten. Kan een 'samenhangende' overeenkomst (zonder geheimhoudingsbeding) dan ook worden ontbonden op het moment dat wordt tekortgeschoten onder de NDA? Voor zover hierover in de hoofdovereenkomst niets is bepaald, is dat uiteraard een kwestie van uitleg. Wanneer men contracten opstelt om onduidelijkheden te voorkomen, zijn dit met name de punten waarmee rekening moet worden gehouden en (vooraf) helderheid over dient te bestaan, zo dunkt ons.

\section{Conclusies}

Het in handelsrelaties contractueel verankeren van geheimhouding ter zake van elkaars gewone bedrijfsgeheimen is als gevolg van de Wbb belangrijk(er) geworden. Partijen kunnen in de regel kiezen voor een NDA of een geheimhoudingsbeding in een meeromvattende overeenkomst. Wij beseffen ons dat een schending van een geheimhoudingsverplichting in rechte veelal moeilijk zal zijn aan te tonen en dat ontbinding van de NDA vaak wordt uitgesloten. Toch hebben wij in deze bijdrage aandacht gevraagd voor de juridische kwalificatie van de NDA en de gevolgen hiervan met betrekking tot de mogelijkheden tot ontbinding.

Een NDA zal volgens ons veelal kwalificeren als een obligatoire overeenkomst. In beginsel is van een wederkerige overeenkomst echter geen sprake, waardoor een NDA in geval van een tekortkoming niet kan worden ontbonden. De rechtsgevolgen van ontbinding zouden volgens ons sowieso beperkt zijn geweest. In het geval vertrouwelijkheid is gewaarborgd in de vorm van een geheimhoudingsbeding in een meeromvattende overeenkomst, ligt dit anders. Ook wanneer sprake is van al dan niet 'in-gecontracteerde', 'samenhangende overeenkomsten' tussen dezelfde partijen, moet men erop bedacht zijn dat de mogelijkheid van ontbinding weer om de hoek komt kijken. Gezien de verstrekkende rechtsgevolgen die een ontbinding in dat geval kan hebben, is het goed dat de opstellers van contracten zich hier bewust van zijn. 